\title{
Chromosomal criteria and taxonomic relationships in the genus Lathyrus (Fabaceae)
}

\author{
Maged M. Abou-El-Enain* \\ Biological Sciences and Geology Department, \\ Faculty of Education, Ain Shams University, \\ Roxy (Heliopolis) P.C. 11341, Cairo, Egypt. \\ * Present address: Science Dept., College of Education for Teachers, \\ P.O.14 (El-Akhdar), Wilayate IBRI, Sultanate of Oman, P.C.516.
}

\begin{abstract}
Abou-El-Enain M.M. 1999. Chromosomal criteria and taxonomic relationships in the genus Lathyrus (Fabaceae).Taeckholmia 19(2): 193-201.

Taxonomic relationships in eight species belonging to five of the 13 currently recognized sections of the genus Lathyrus have been discussed and their phylogeny based on chromosomal criteria is suggested. A diploid number of $2 n=14(x=7)$ has been found in all species studied and thus $x=7$ is confirmed as the basic number in the genus. Karyotypes of the examined species have metacentric and submetacentric chromosomes that are variable in length. The retention of $L$. pratensis in the section Pratensis is confirmed. The assignment of $L$. hirsutus to section Lathyrus and of $L$. cicera and $L$. sativus to section Clymenum are supported. The present data revealed that L. pratensis is the most likely ancestral type in the genus and that Layhyrus represents a natural monophyletic group in the tribe Vicieae.
\end{abstract}

Key words: Chromosomes, karyotype, Lathyrus, Taxonomy

\section{Introduction}

The genus Lathyrus is well known legume in agriculture, its species are used as ornamentals, green manure, fodder plants and for erosion control as well as soil improvement (Whyte et al., 1953; Dogan et al. 1992). Species of the genus are distributed in the temperate regions of Northern Hemisphere with center of diversity in Mediterranean countries (Goyder, 1986). The genus belongs to the tribe Vicieae of family Fabaceae and comprises about 160 annual and perennial herbaceous creeping or climbing species (Schifino-Wittmann et al. 1994; Asmussen and Liston, 1998). The species of Lathyrus are classified into two subgenera i.e. Lathyrus and Orobus with a variable number of sections (Davis, 1970; Kupicha, 1983; Dagan et al., 1992; Asmussen and Liston, 1998).

The chromosome count of $2 n=14$ was reported in most of Lathyrus species. (see, Fedorov, 1969). However, alternative numbers have been observed within the genus. A diploid number of $2 n=12$ and 16 was recorded in each of L. subrotundus and L. davidii respectively. Polyploid numbers have also been recorded in some Lathyrus species. A tetraploid number of $2 n=4 x=28$ was scored in each of L. maritimus, L. odoratus, $L$. venosus (Fedorov, 1969) and L. pratensis (Gutierrez et al., 1994) whereas a hexaploid number of $2 n=6 x=42$ was observed in L. palustris (Sybenga, 1995). From these and other reports (e.g. Goldblatt, 1984; 1985; 1988; Goldblatt and Johnson, 1991), $x=7$ has been encountered in almost all species of the genus.

Received 11 April 1999. Revision accepted 30 November 1999. 
A number of studies have been focused on the role of chromosomal criteria for classification and phylogeny in Lathyrus. Yamamoto et al. (1984) recorded three karyotype groups in section Cicercula; as defined by Davis (1970); based on variation in satellited chromosomes. Wallace and Callow (1993) reported a considerable variation in genome length and the content of moderately repetitive DNA in some species of section Lathyrus. El-Shanshoury (1997) pointed out that, species of sections Clymenum, Nissolia and Aphaca have larger chromosome complement than those in section Cicercula. These studies and others (e.g. Datta, 1955; Chaudhari, 1966; Rees and Hazarica, 1969; SchifinoWittmann et al., 1994) revealed that, karyotype of most species of Lathyrus have metacentric- and submetacentric chromosomes.

Phylogenetic hypotheses have also been concluded for Lathyrus species based on karyological criteria; especially the chromosome number and the mean chromosome length. Goldblatt (1981a) suggested $x=7$ or 8 for the tribe Vicieae. He supported the view of Kupicha (1977) that $x=7$ of Lathyrus is derived through hypoploidy from ancestral $x=8$. On the other hand, Rees and Hazarika (1969), Broich (1989) and El-Shanshoury (1997) concluded that evolution of the genus Lathyrus, has resulted in large increase in chromosome length. However, Wallace and Callow, (1993) and Ahmad and Narayan (1994) argued that evolution has resulted in a reduction in chromosome length and DNA content.

Chromosomal studies on the interspecific and phylogenetic relationships in the genus Lathyrus are still limited. The present work deals with using the chromosomal criteria to address the specific and phylogenetic relationships of eight species of Lathyrus.

\section{Materials and Methods}

Seeds of the species studied were provided by the Institute of Plant Genetics \& Horticulture (IPK) gene bank, Gatersleben, Germany and the plant genetic resources conservation unit of the United States Department of Agriculture (USDA), Georgia, USA. The source, origin and sectional delimitation, as proposed by Kupicha (1983), of the species studied are given in table 1 . For the cytological preparations, young and healthy root tips were taken from seedlings that had been germinated in Pertri-dishes, pretreated for $3-4 \mathrm{hr}$ in $0.05 \%$ colchicine solution at room temperature, washed and fixed in 3:1 absolute ethanol: glacial acetic acid overnight. The root tips were hydrolyzed for 6 min in $1 \mathrm{M} \mathrm{HCI}$ at $60^{\circ} \mathrm{C}$, washed and stained in Feulgen's solution for $1-2 \mathrm{hr}$. Stained tips were squashed in a drop of $1 \%$ acetocarmine and permanent cytological preparations were made by mounting in Euparal.

Cells with a good spread of chromosomes were photographed using a Carl-Zeiss Photomicroscope III and prints were enlarged to a magnification of 2500. Karyotypes of the species were made by cutting out individual chromosomes and arranging them in homologous pairs in order of their length and arm ratio. The chromosomes were classed by the arm ratio according to Levan et al. (1965). Karyotype criteria were measured from 5 to 10 chromosome complements; these are mean length in $\mu \mathrm{m}$, mean arm ratio (M. $\mathrm{r}$ value). The standard error (SE) for the means of these parameters was also calculated. Karyotype asymmetry has been estimated using the equation of Huziwara (1962) [TF\% = sum of short arm lengthlsum of total chromosome length $X$ 100]. The asymmetry based 
on the ratio between the chromosome arms $A_{l}$ and length $A_{2}$ have been estimated for each species using the equations of Zarco (1986) as follows:

$$
A_{1}=1-\frac{\sum_{0-1}^{n} \frac{b i}{B i}}{n_{i}} \text { and } A_{2}=\frac{S}{\bar{x}}
$$

Where $A_{l}$ is the intrachromosomal asymmetry index that ranges from zero to one. The equation is formulated in order to obtain lower values when chromosomes tend to be metacentric. $n i$ is the number of homologous chromosome pairs or groups. $b i$ is the average length for short arms in every homologous chromosome pair or group and $B i$ is the average length for their long arms. On the other hand, $A_{2}$ is the interchromosomal asymmetry index, where $x=$ mean chromosome length (MCL) and $S$ is its standard deviation.

\section{Results}

A summary of the cytological data of the species studied is given in table 1 and their karyotypes are illustrated in figs. 1-8. All species studied were found to have a somatic chromosome number of $2 n=14$ with a base number of $x=7$. Measurements of the mean chromosome length (MCL) of the species studied have revealed that the highest value $(6.85 \pm 0.55 \mu \mathrm{m})$ is recorded in $L$. aphaca, while the lowest value $(4.21 \pm 0.20 \mu \mathrm{m})$ is found in L. pratensis. Relatively long chromosomes were recorded in the remaining species studied i.e. L. hirsutus $(\mathrm{MCL}=6.70+0.59 \mu \mathrm{m})$, L. sativus $(6.18+0.51 \mu \mathrm{m})$, L. clymenum $(6.14 \pm 0.35 \mu \mathrm{m})$, L. cicera $(5.86 \pm 0.60 \mu \mathrm{m})$, L. ochrus $(5.65 \pm 0.43 \mu \mathrm{m})$ and L. nissolia $(5.14 \pm 0.55 \mu \mathrm{m})$. The most variable chromosomes in length are found in $L$. cicera (SE of $\mathrm{MCL}=0.60 \mu \mathrm{m}$ ), whereas the most similar chromosomes are scored in L. pratensis (SE of MCL $=0.20$ ). The variation in length among chromosomes of the species studied is also reflected in the values of $A_{2}$, lower $A_{2}$ values are scored in species with lower degree of variation in length.

Values of the mean arm ratio (M. r-ratio) indicate that the karyotypes of the species studied have metacentric to submetacentric chromosomes. This value ranges from a lowest of $1.36 \pm 0.07$ in L. sativus and a highest of $1.95 \pm 0.19$ in L. clymenum. The degree of karyotype asymmetry as indicated by TF\%-values ranges between $42.19 \%$ in $L$. sativus and $34.05 \%$ in L. clymenum. $A_{l}$ values range between 0.896 in L. sativus and 0.926 in L. clymenum and indicate a high degree of karyotype symmetry in most of the species studied. 
Table 1: Source, origin, and sectional delimitation of the studied species of Lathyrus and summary of their karyological criteria

\begin{tabular}{|c|c|c|c|c|c|c|c|c|c|c|c|c|c|}
\hline \multirow{2}{*}{ No. } & \multirow{2}{*}{ Species } & \multirow{2}{*}{ Source } & \multirow{2}{*}{ Origin } & \multirow{2}{*}{ Section } & \multirow{2}{*}{$2 n$} & \multirow{2}{*}{$\mathrm{x}$} & \multirow{2}{*}{$\begin{array}{c}\mathrm{MCL} \pm \mathrm{SE} \\
(\mu \mathrm{m})\end{array}$} & \multirow{2}{*}{$\begin{array}{c}\text { M. r-ratio } \\
\pm \mathrm{SE}\end{array}$} & \multicolumn{3}{|c|}{$\begin{array}{l}\text { Karyotype } \\
\text { asymmetry }\end{array}$} & \multicolumn{2}{|c|}{$\begin{array}{c}\text { Chromosome } \\
\text { type }\end{array}$} \\
\hline & & & & & & & & & $\mathrm{TF} \%$ & & & $\mathrm{~m}$ & $\mathrm{sm}$ \\
\hline 01 & L. aphaca $\mathrm{L}$. & IPK & Italy & Aphaca & 14 & 7 & $6.85 \pm 0.55$ & $1.54 \pm 0.07$ & 39.07 & 0.908 & 0.212 & 6 & 1 \\
\hline 02 & L.cicera $\mathrm{L}$. & USDA & Spain & Lathyrus & 14 & 7 & $5.86 \pm 0.60$ & $1.70 \pm 0.19$ & 37.71 & 0.914 & 0.271 & 4 & 3 \\
\hline 03 & L. clymenum $\mathrm{L}$. & IPK & Morocco & Clymenum & 14 & 7 & $6.14 \pm 0.35$ & $1.95 \pm 0.19$ & 34.05 & 0.926 & 0.151 & 2 & 5 \\
\hline 04 & L. hirsutus L. & IPK & Egypt & Lathyrus & 14 & 7 & $6.70 \pm 0.59$ & $1.60 \pm 0.14$ & 38.93 & 0.909 & 0.233 & 4 & 3 \\
\hline 05 & L. nissolia L. & IPK & Turkey & Nissolia & 14 & 7 & $5.14 \pm 0.55$ & $1.49 \pm 0.10$ & 40.67 & 0.902 & 0.283 & 5 & 1 \\
\hline 06 & L. ochrus (L.) DC. & USDA & Portugal & Clymenum & 14 & 7 & $5.65 \pm 0.43$ & $1.50 \pm 0.08$ & 40.75 & 0.902 & 0.201 & 5 & 1 \\
\hline 07 & L. pratensis L. & IPK & Austria & Pratensis & 14 & 7 & $4.21 \pm 0.20$ & $1.42 \pm 0.06$ & 41.36 & 0.899 & 0.126 & 5 & 1 \\
\hline 08 & L. sativus L. & IPK & Egypt & Lathyrus & 14 & 7 & $6.18 \pm 0.51$ & $1.36 \pm 0.07$ & 42.19 & 0.896 & 0.218 & 7 & - \\
\hline
\end{tabular}

IPK = Institute of Plant Genetics \& Horticulture gene bank, Germany; USDA = United States Department of Agriculture, USA; $2 \mathrm{n}=$ Diploid chromosome number; $\mathrm{x}=$ Basic chromosome number; MCL = Mean chromosome length, $\mathrm{SE}=$ Standard error; $\mathrm{M}$. r-ratio $=$ Mean arm ratio; $\mathrm{TF} \%=$ Total form percentage, $A_{l}=$ Intrachromosomal asymmetry index, $A_{2}=$ Interchromosomal asymmetry index $; \mathrm{m}=$ Metacentric chromosomes and $\mathrm{sm}=$ Submetacentric chromosomes. 


\section{Discussion}

The uniformity of the basic chromosome number $(x=7)$ in the species studied confirms earlier reports on these species (Fedorov, 1969; Goldblatt; 1981b, 1984, 1985, 1988). This could also support the view of Broich (1989); Sin and Alton (1990); Wallace and Callow (1993) that $x=7$ is the primary basic number in the Old World Lathyrus. The similarity among the species studied in chromosomal criteria, particularly in karyotype symmetry, is in agreement with the results of some previous studies (Datta, 1955; Chaudhari, 1966; Rees and Hazarica, 1969; Yamamoto et al. 1984). The numerical constancy and morphological similarity in the chromosomes of Lathyrus is reflected in the successful hybridization between some species (Hammet et al., 1994) .

Davis (1970) and Kupicha (1983) placed the two species $L$. aphaca and $L$. pratensis in two different sections i.e. Aphaca and Pratensis, respectively. However, Dagan et al. (1992) grouped these two species in one section i.e. Aphaca of subgenus Lathyrus. The present data (Table 1; Figs. 1\&7) confirms the separation of the two species in two different sections i.e. Aphaca and Pratensis as proposed by Davis (1970) and Kupicha (1983). The karyotype of L. aphaca is characterized from that of $L$. pratensis by longer chromosomes and higher degree of asymmetry due to variation in length of individual chromosomes. Morphologically, the angled glabrous stem, parallel venation and the glabrous pod characterize L. aphaca. The variation in the phytochemical structure (Reynaud et al., 1981; Ranabahu and Harborne, 1993) between the two species could further support the latter view.

Davis (1970) included the species L. cicera, L. hirsutus and L. sativus in section Cicercula. However, Kupicha (1983), who merged this section in section Lathyrus treated these species as belonging to section Lathyrus. On the other hand, Dogan et al. (1992) retained $L$. hirsutus in the section Cicercula and treated $L$. cicera and $L$. sativus as belonging to section Clymenum. The present data (Table 1; Figs. 2,4 \& 8) support the separation of $L$. hirsutus from the other two species i.e. L. cicera and $L$. sativus as proposed by Dogan et al. (1992). MCL values revealed that $L$. hirsutus has longer chromosomes than those in L. cicera and L. sativus. Morphologically, L. hirsutus is characterized from the other two species by the parallel leaflet venation, silky pods, tuberculate based hairs, sessile glandular indumentum and wingless seeds. The latter character distinguishes the species of section Cicercula. On the other hand, L. cicera and L. sativus are similar in the compressed, oblong-linear, beaked, reticulate- veined corolla and pods with prominent midrib on each valve. These are the characteristics of the species in section Clymenum.

Senn (1938) reported that the basic chromosome number of $x=8$ is the most frequent number in the subfamily Papilionoideae. He postulated that other numbers arose as a result of aneuploid loss or gain or duplication of this number. However, Goldblatt (1981a) suggested $x=14$ for the subfamily Papilionoideae (Fabaceae) and $x=7$ for the tribe Vicieae. Moreover, he supported the view of Kupicha (1977) that $x=7$ of Lathyrus is derived through hypoploidy from ancestral $x=8$. In the present study, the recorded $x=7$ and the presence of $x=6,7 \& 8$ as recorded in previous reports might indicate that aneuploidy is common in the genus. This observation is supported by the score of $2 n=9$, 14, 16, 21 \& 28 in L. pratensis (Fedorov, 1969; Gutierrez et al., 1994) and could contradict the view of Kupicha (1977) and Goldblatt (1981a) that Lathyrus is derived 
through aneuploid reduction from $x=8$. These data might indicate that $x=7$ is the primary basic number from which other numbers could have evolved.

Within the genus Lathyrus, the known chromosome counts are known for $64 \%$ of the total number of species; $x=7$ is found in the vast majority of species $(86.00 \%)$. Polyploids derived from this number are recorded in $12.6 \%$ of the species whereas the haploid numbers of $n=6 \& 8$ are reported in the remaining species. From this statistics and the results of the present study, $x=7$ is confirmed as the basic number from which other numbers are derived by aneuploid changes. On the other hand, the high frequency of $x=7$ in the genus supports the presence of environmental selection pressure favoring higher number of linkage groups in the karyotype. This view has previously been expressed, based on the similarity in DNA content, either in Lathyrus (Narayan and Durrant, 1983; Ahmad, 1993) or in other genera e.g. Orchid (Cox et al., 1998).

Stebbins (1974) and Moore (1978) discussed karyotype variation in the degree of symmetry among the plant genera and species. Symmetrical karyotypes are considered more primitive than asymmetrical ones. The evolution of the latter from the former has been recorded in several genera, for example Crotalaria (Gupta and Gupta, 1978), Phaseolus (Sarbhoy, 1980), Sesbania (Abou-El-Enain et al., 1998) and several others. In the present study, high degrees of karyotype asymmetry; as indicated by $A_{l}$ value; are recorded in the annual species having longer chromosomes i.e. L. aphaca, L. hirsutus and L. sativus. This might support the view of Rees and Hazarika (1969), Broich (1989) and El-Shanshoury (1997) that evolution has resulted in large increase in chromosome size in Lathyrus species. Consequently, it can be concluded that L. pratensis of the subgenus Orobus is most likely ancestral type in the genus since it has the shortest genome length among the species studied (Table $1 \&$ Fig. 7). The primitiveness of species in the subgenus Orobus have previously been evidenced by Kupicha (1983) who reported that, the primitive ancestral stock of Lathyrus has had the characters of section Orobus that originated at high latitudes in the Old World and migrated to North America.

In the light of the interspecific similarity in karyotype asymmetry among the species studied herein, as well as in previous reports (Datta, 1955; Chaudhary, 1966; Rees and Hazarica, 1969; Schifino-Wittmann et al., 1994) and the interspecific crossing ability reported by Hammet et al. (1994), it can be concluded that the genus Lathyrus might be considered as a natural monophyletic group within the tribe Vicieae. Similar view has previously been concluded by Asmussen and Liston (1998) based on the cladistic analysis of cpDNA restriction site characters in the genus Lathyrus.

\section{Acknowledgment:}

I'm grateful to Prof. Abdelfattah Badr, professor of genetics and head of Botany Department Faculty of Science, Tanta University for helpful advice and valuable criticism of the mannscript.

\section{References}

Abou-El-Enain, M.; El-Shazly, H. and El-Kholy, M., 1998: Karyological studies in some African species of the genus Sesbania. Cytologia 63: 1- 8 .

Ahmad, S.D., 1993: Molecular variability and heritability of ribosomal RNA genes in Lathyrus species. J. Agric. 9: 55-60. 
Ahmad, S.D. and Narayan, R.K., 1994: Evolutionary changes in genomic DNA constituents and the duration of cell cycle in Lathyrus species. Cytologia 59:445-451.

Asmussen, C.B. and Liston A., 1998: Chloroplast DNA characters, phylogeny, and classification of Lathyrus. Amer. J. Bot. 85: 387-396.

Broish, S.L., 1989: Chromosome numbers of North American Lathyrus. Madrono 36: 4148.

Choudhari ,P.R., 1966: Karyotypic analysis of different strains of Lathyrus odoratus. Trans. Bas. Res. Inst. 29: 97-104.

Cox, A.V.; Abdelnour, G.J.; Bennett, M.D. and Leitch, I.J., 1998: Genome size and karyotype evolution in the slipper orchids (Cypripedioideae: Orchidaceae). Amer. J. Bot. 85: 681- 688.

Datta, P.C., 1955: Studies on the structure and behaviour of chromosomes of a few species of the genus Lathyrus as means of detecting inter relations. Genet. Iber. 7: 85-115.

Davis, P.H., 1970: Lathyrus. In: Flora of Turkey and the East Aegean Islands. Vol. 3. Pp. 328-369. Edinburgh University Press, Edinburgh.

Dogan, M.; Kence, A. and Tigin, C., 1992: Numerical taxonomic study on Turkish Lathyrus (Leguminoseae). Edinb. J. Bot. 49: 333-341.

El-Shanshoury, A.R., 1997: The use of seed proteins revealed by SDS-PAGE in taxonomy and phylogeny on some Lathyrus. Biol. Plant. 39:553-559.

Fedorov, A.A., 1969: Chromosome numbers of flowering plants. V.L. Komarov Botanical Inst., Leningrad. (in Russian with Latin nomenclature)

Goldblatt, P. 1981a: Cytology and the phylogeny of Leguminosae, in: Polhill, R.M. and Raven, P.H. (ed.): Advances in Legume Systematics. Part 2 , Royal Botanic Gardens, Kew. PP. 427-463.

1981b: Index to plant chromosome numbers 1975-1978. Monographs in Systematic Botany, V.5. Missouri Botanical Garden. Saint Louis. 1984: Index to plant chromosome numbers 1979-1981. Monographs in Systematic Botany, V.8. Missouri Botanical Garden. Saint Louis. 1985: Index to plant chromosome numbers 1982-1983. Monographs in Systematic Botany, V.13. Missouri Botanical Garden. Saint Louis. , 1988: Index to plant chromosome numbers 1984-1985. Monographs in Systematic Botany, V.23. Missouri Botanical Garden. Saint Louis. , and Johnson, D.E. (ed.), 1991: Index to plant chromosome numbers 19881989. Monographs in Systematic Botany, V.40. Missouri Botanical Garden. Saint Louis.

Goyder, D.J. 1986. The genus Lathrus. In A.K. Kaul and D. Combes. (ed.) Lathyrus and Lathyrism, 3-7. Third World Medical Research Foundation, New York.

Gupta, R. and Gupta, P.K., 1978: Karyotypic studies in the genus Crotalaria Linn. Cytologia 43 : 357 - 369.

Gutierrez, J.F.; Vaquero, F. and Vences, F.J.,1994: Allopolyploid vs. autopolyploid origins in the genus Lathyrus. Heredity 73: 29-40.

Hammett, K.R.; Murray, B.G.; Markham, K.R. and Hallett, I.C., 1994: Interspecific hybridization between Lathyrus odoratus and L. belinensis. Int. J. Pl. Sciences 155:763-771. 
Huziwara, Y., 1962: Karyotype analysis in some genera of Compositae VIII. Further studies on the chromosomes of Aster. Amer. J. Bot. 49 : 116-119.

Kupicha, F.K., 1977: The delimitation of the tribe Vicieae and the relationships of Cicer. Bot. J. Linn. Soc. 74: 131-162.

1983: The infrag-eneric structure of Lathyrus. Notes Roy. Bot. Gard. Edinb. 41: 209-244.

Levan, A.; Fredga, K. and Sanders, A.A., 1965: Nomenclature for centromeric position on chromosomes. Hereditas 52 : 201-220.

Moore, D.M., 1978: The chromosomes and plant taxonomy. In : H.E. Street (ed.) : Essays in Plant Taxonomy. Acad. Press, London, New York. pp. 38 - 56.

Narayan, R.R. and Durrant, A., 1983: DNA distribution Chromosomes of Lathyrus species. Genetica 61: 47-53.

Ranabahu, P. and Harborne, J. B., 1993: The flavonoids of the genus Lathyrus and a comparison of flavonoid patters within the tribe Vicieae. Biochem. Sys. \& Ecol. 21: 715-722.

Rees, H.H. and Hazarika, M.H., 1969: Chromosome evolution in Lathyrus. Chromosome Today 2: 157-165.

Reynaud, J.; Ismail, A. and Jay, M., 1981: Flavonoid glycosides of Lathyrus pratensis. Phytochemestry 20: 205- 214.

Sarbhoy, R.K., 1980: Karyological studies in the genus Phaseolus Linn. Cytologia 45: 363 - 373.

Schifino-Wittmann, M.T.; Lau, A.H.; and Simioni, C., 1994: The genera Vicia and Lathyrus in Rio Grande Do Sul (Southern Brazil): Cytogenetics of native, naturalized and exotic species. Rev. Brazil. Genet. 17: 313-319.

Senn, H.A., 1938: Chromosome number relationships in the Leguminosae. Bibliographia Genetica 12 : 175-336.

Sin, A. and Alton, Y., 1990: Karyological studies on some Turkish Lathyrus L. species. Turk. Bot. Der.15: 50-56.

Stebbins, G.L., 1974: Flowering Plants. Evolution above the species level. Edward Arnold (Publ.). Ltd., London.

Sybenga, J., 1995: Meiotic pairing in autohexaploid Lathyrus: a mathematical model. Heredity 75:343-350.

Wallace, A.J. and Callow, R.S., 1993: Synaptic responses to concerted genomic evolution in Lathyrus. II- Intragenomic effects. Heredity 70: 92-97.

Whyte, R.O.; Nilsson-Leissner, G.; and Trumble, H. C., 1953: Legumes in Agriculture. FAO, Rome.

Yamamoto, K.; Fujiwara, T. and Blumenreich, I.D., 1984: Karyotypes and morphological characteristics of some species of the genus Lathyrus. Jap. J. Breed. 34: 273284.

Zarco, C.R., 1986: A new method for estimating karyotype asymmetry. Taxon 35 : 526530. 

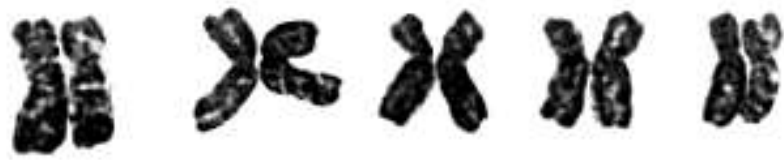

影

88

28
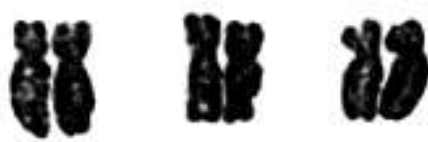

28

68. 83

39
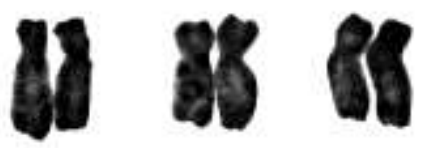

of

8
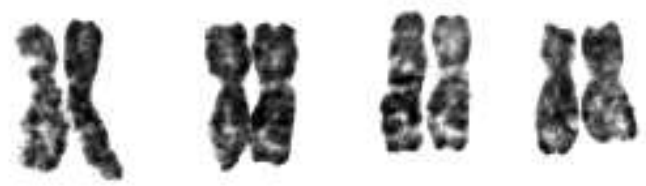

B.

80

ำ

5 雾

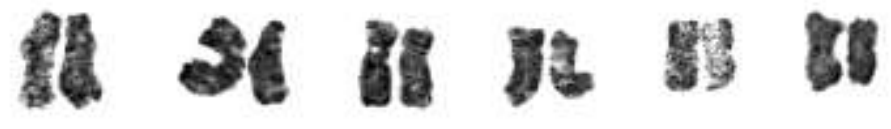

6
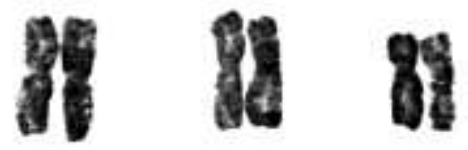

จง

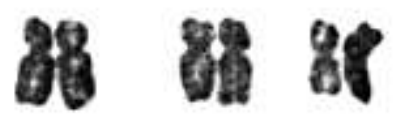

7 题

ม

or 1

敂 is 8

8 की

篦

路

ํํำ

瀻

Figs. 1-8: Karyotype in Lathyrus aphaca (1), L. cicera (2), L. clymenum (3), L. hirsutus (4), L. nissolia (5), L. ochrus (6), L. pratensis (7) and L. sativus (8). Bar $=5 \mu \mathrm{m}$ 